\title{
A series of unfortunate events: how the battle to save an urban wetland was both won and lost
}

\author{
Y GOVENDER-RAGUBEER, ${ }^{1}$ J MEEUWIS ${ }^{2}$ AND TMORTON MCKAY ${ }^{3}$
}

\begin{abstract}
Many urban wetlands in South Africa are either lost or degraded in the name of development. Of those remaining, most are less than pristine, even canalised, dredged, drained or filled. This is partly because urban wetlands are often found in strategic locations, and, as such are considered prime development land. A typical example is that of the Libradene Wetland, in Boksburg, Gauteng, which was partially destroyed by an attempt to construct a petrol station on it. This study explores how and why the fate of this particular wetland was sealed. The study explored the roles of the developer, the professionals in the paid services of the developer and various government officials. Although construction in the wetland eventually ceased, no one has been brought to book and no rehabilitation has taken place. The study concluded that although South African wetlands are well protected by legislation [the National Environmental Management Act (107 of 1998); the Environmental Conservation Act (73 of 1989) and the Conservation of Agricultural Resources Act (43 of 1983)] the assumption is that developers will comply. If they don't, then enforcement is difficult. In this case enforcement was slow, during which time the developer continued building and the result was significant degradation. The study makes a number of recommendations: (i) the fragmented administration of environmental legislation pertaining to wetlands should be consolidated under one government department; (ii) relationships between the respective authorities at all government levels needs strengthening; (iii) public participation processes need to be more robust and (iv) the national wetlands database needs to be used more effectively.
\end{abstract}

Key words: urban wetlands; EIAs; eco-crusaders; public participation

\section{Introduction}

In December 2004, construction of a petrol station on a small urban wetland in Libradene Boksburg, Gauteng commenced. Although community members and wetland stakeholders voiced their concern, construction continued. Eventually in December 2005 a provincial

1. Yageshni Govender-Ragubeer is attached to the Department of Geography, Environmental Management and Energy Studies, University of Johannesburg, South Africa, P O Box 524 Auckland Park 2006.

2. June Meeuwis is attached to the Department of Geography, Environmental Management and Energy Studies, University of Johannesburg, South Africa, P O Box 524 Auckland Park 2006.

3. Corresponding author Tracey Morton McKay is attached to the Department of Environmental Sciences, University of South Africa, South Africa, Pvt Bag X 6 Florida 1710, traceymckay02@me.com and traceyjillmckay@gmail.com. Acknowledgements: The authors are most grateful to Ms Nicole Barlow and Ms Henretta Kekane who provided us with much of the original primary documents upon which this study rests. Ms Wendy Job of the UJ Cartographic Unit for the maps and the UJ library, and critical reviewers for their comments. 
government department, Gauteng Department of Agriculture, Conservation and Environment (GDACE), issued a directive to both the developer/landowner and Sasol Oil (Pty) (Ltd) which resulted in the cessation of construction activities (Tip, 2006). By then, however, the material impact on the wetland and associated watercourse was extensive. Canalisation had occurred, building rubble had been dumped directly into the watercourse, and the underlying rock structure had been altered during the installation of the underground petrol tanks. The socially-beneficial attributes of the wetland such as its aesthetic appeal, had also been greatly reduced. Cessation of construction was followed by a series of legal actions. To date the petrol station remains incomplete, no one has been held accountable for the legal violations and rehabilitation plans have been suspended. It is argued here that although urban wetlands bring significant benefits to cities, the case of the Libradene wetland illustrates both how and why urban wetlands become degraded and lost (Kotze et al., 1995; Heydorn, 1996; Braak et al., 2000; Day, 2009; McInnes, 2010). This loss of wetlands seems to be occurring despite the embodiment of 'environmental rights' into the South African Constitution (1996) and the promulgation of legislation designed to protect, conserve and, if necessary, rehabilitate wetlands (Van Niekerk, 2004). Understanding how and why the Libradene wetland was degraded, despite legislation protecting it, can inform policy makers, government officials and wetland specialists on how threats can be managed. In particular, the development highlights the key challenges regarding the management of conflicts between economic development and environmental protection authorities are faced with. Furthermore, it is predicted that conflicts over their use and protection will escalate in the future making wetlands one of the most endangered ecosystems in South Africa (Dini et al., 1998; Braak et al., 2000; Cillers et al., 2003; Armstrong, 2009). This is especially true for small, seemingly 'insignificant' wetlands, which are largely overlooked, with no national policy in place for their protection (Kotze et al., 1995; Dini et al., 1998). This case study highlights the urgent need for such a policy.

\section{Objectives}

The study had a number of aims: (1) to chart the sequence of events relating to the partial building of the petrol station in order to understand who did what, when; (2) to analyse South Africa's legislation pertaining to wetlands to establish if the legislation was robust enough to protect the wetland; (3) to establish if the legislation was enforced; and (4) to ascertain who should be held responsible for the partial destruction of the Libradene wetland. In order to analyse the data and build a sequence of events, an historical time-line was constructed using court records, newspapers, the basic scoping report, various other specialist reports, correspondence and records of public objections. Lastly, data and events were verified through consultation with Ms Nicole Barlow (a local resident) who played a key role in the whole Libradene court case, a wetland Dr John Dini (of SANBI), Mr Umesh Bahadur (formerly of GDACE) and Mr Piet-Louis Grundling (a wetland consultant). For clarity purposes, Figure 1 outlines the various stakeholders who were directly involved in the events. 


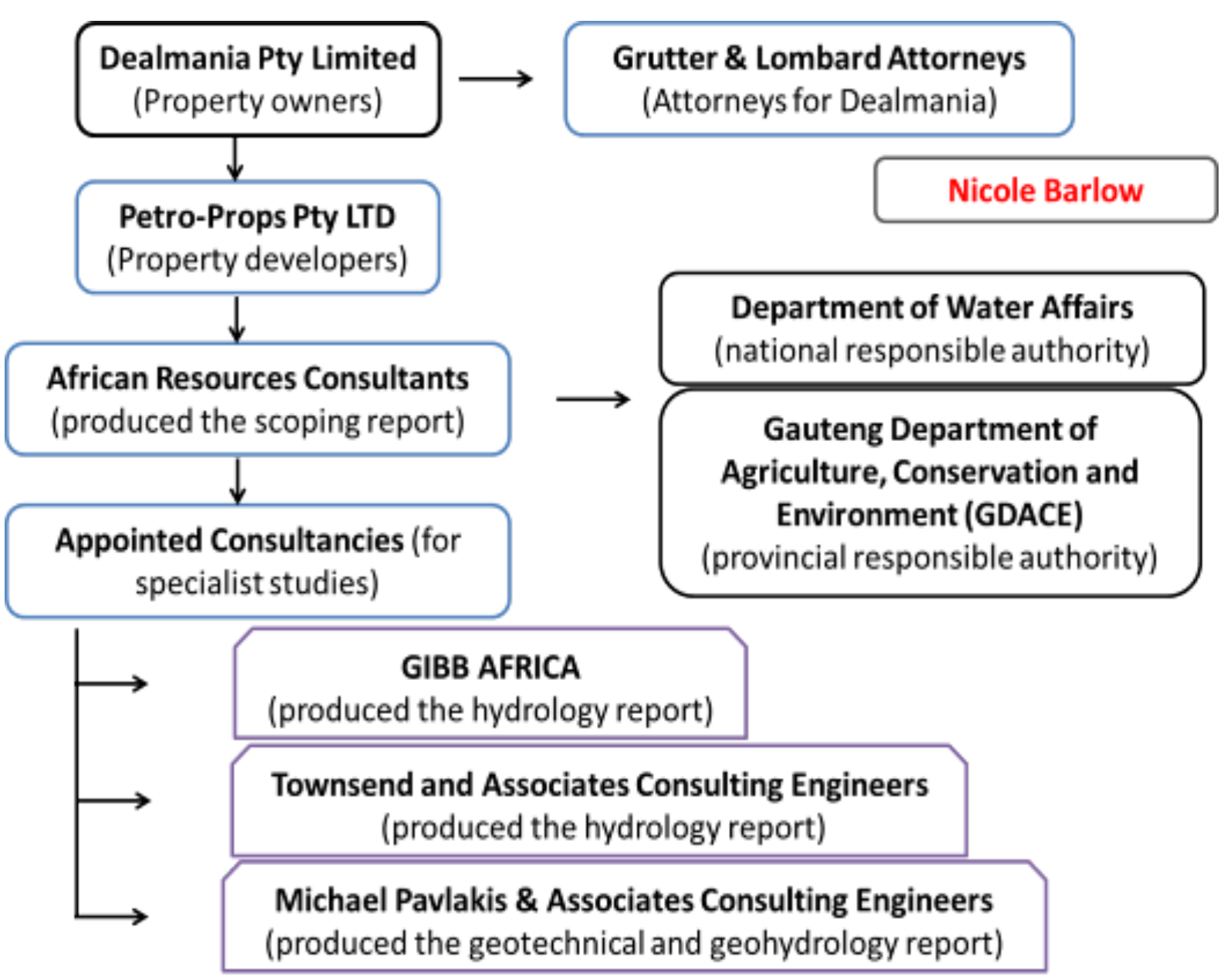

Figure 1: Stakeholders directly involved in the Libradene case.

The study area

The Libradene wetland, a small and hydrologically insignificant one, is located in a highly urbanised part of Gauteng, dissected by a major road and bounded by minor residential roads (see Figure 2). The total area of the wetland measures 7,103ha (ARC, 2002). The existence of a wetland was confirmed using on-site identification of primary field indicators, such as visual observations of inundation, soil saturation; water marks, sediment deposits and evidence of drainage flow (Dlamini, 2011). A railway siding, the Cindarella dam, vacant land and a slimes dam are situated downstream, in a westerly direction. To the north and south lie residential suburbs; to the east (upstream) is a recreational park. The development took place on Erf 342, Libradene Extension 2, Portion 125 of the farm, Leeuwpoort 113 IR (LRI, 2011). Although not officially zoned for any activity, it would be best to describe it as agricultural land since it was originally part of a farm. 


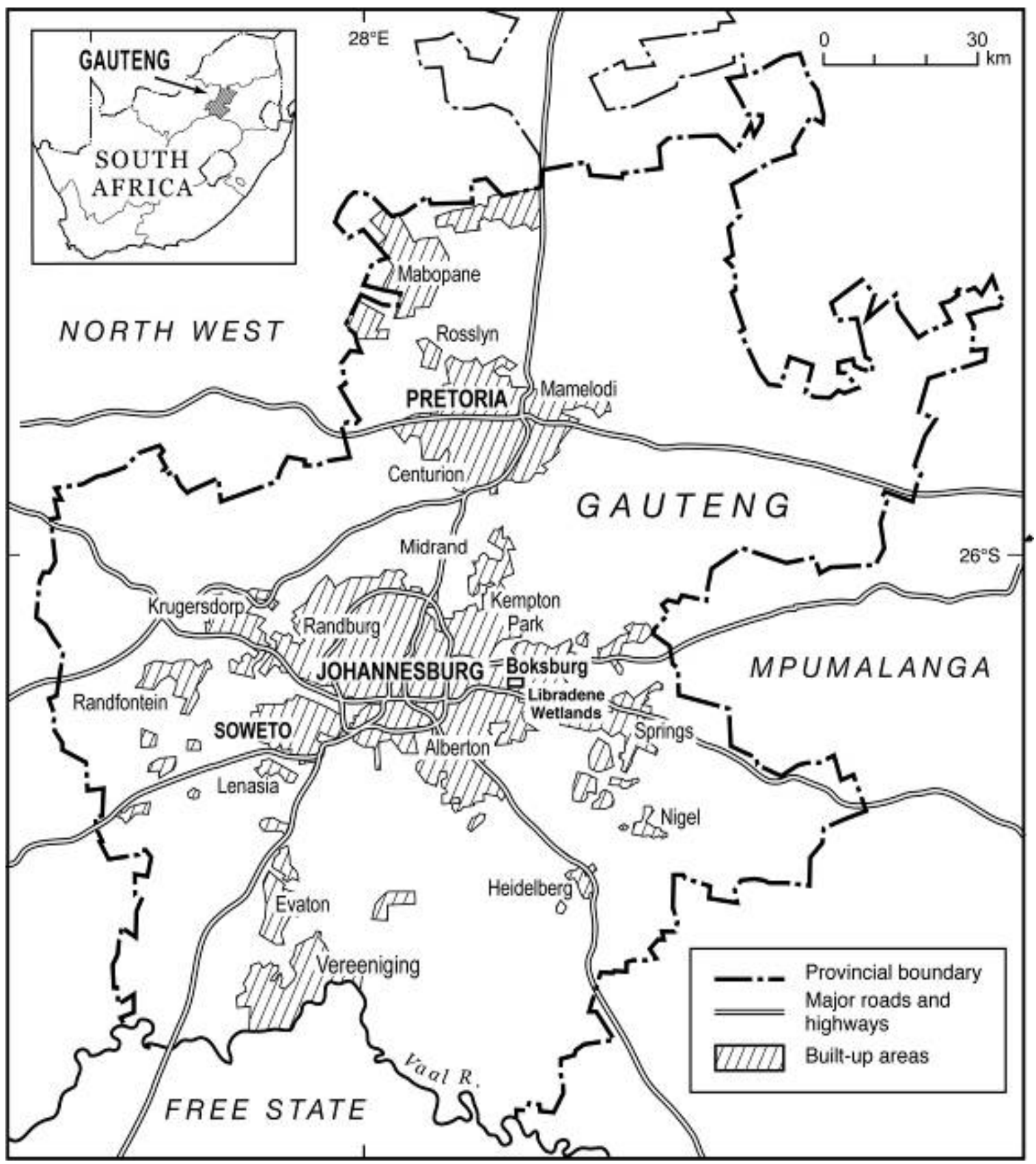

Figure 2: Location and geographical extent of the Libradene wetland

The wetland is bisected by a watercourse, the Elsburg Spruit, a perennial tributary of the Natal Spruit and eventually flows into the Vaal River, Gauteng's major water source (see Figure 3). The underlying rock is dolomitic belonging to the Chuniespoort Group (part of the Transvaal System) and is a karst aquifer (Dlamini, 2011). The hydrological significance of this aquifer has not been established. The southern part of the area is underlain by clayish, silty sands that vary in depth from shallow to deep. These soils are usually highly compressible and potentially collapsible. The wetland is a typical hillslope, palustrine wetland, dominated by vegetation such as trees, shrubs and persistent herbaceous plants (Tiner, 1999). The wetland falls within the grassland biome and the following vegetation types are represented: (a) Soweto Highveld Grassland which is highly endangered as only $0.2 \%$ is currently protected, and (2) Tsakane Clay Grassland - also highly endangered as only $1.5 \%$ is currently protected (Mucina \& Rutherford, 2006). 


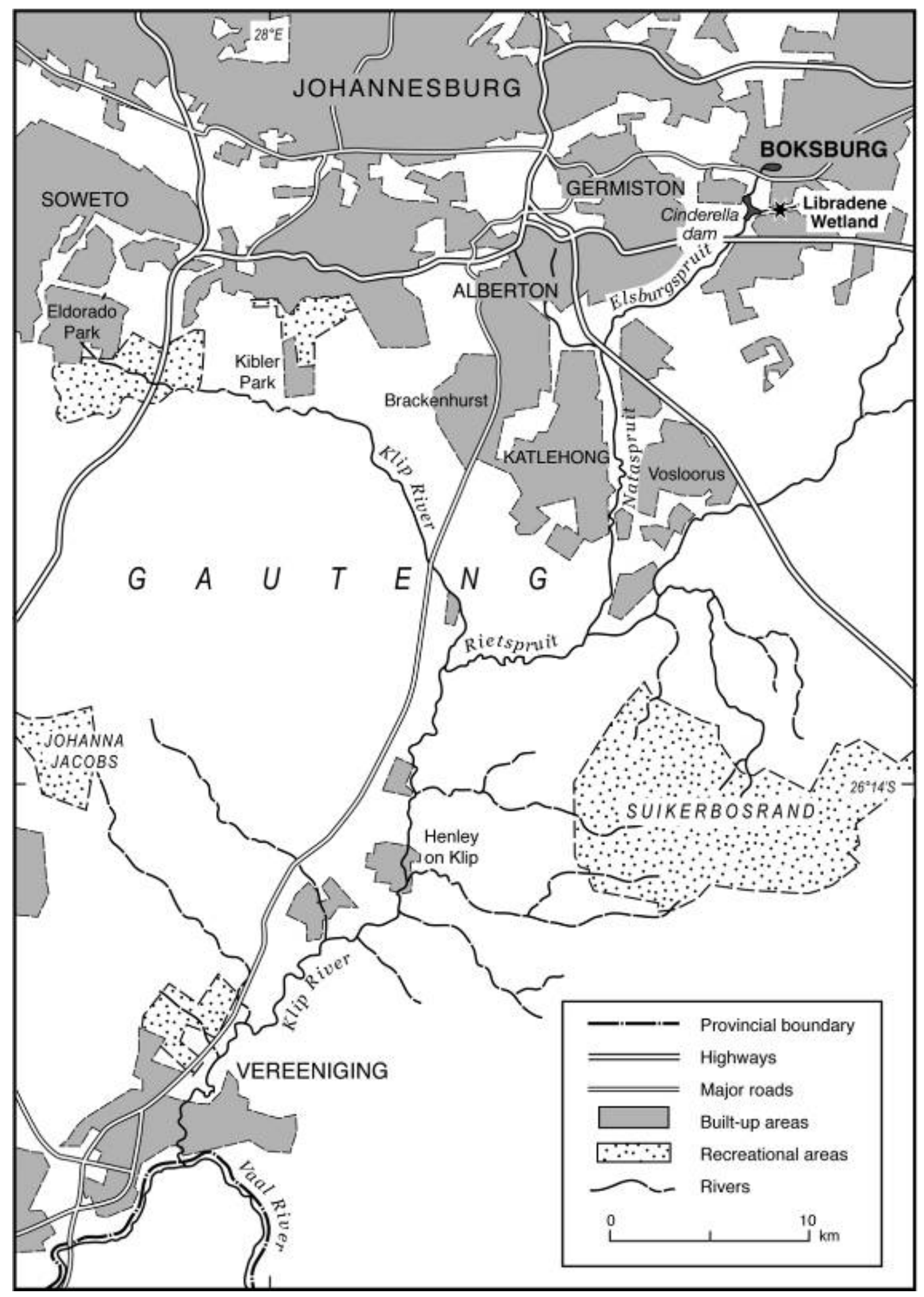

Figure 3: Surface catchment map indicating with the Libradene wetland indicated 
The most common vegetation are reeds - Phragmites australus (common reed), Typha capensis (bulrush or palmiet), Juncus spp. (soft rush), Hyparrhenia birta (thatching grass), Cyperaceae ssp. (sedges or biesies) and Imperata cylindrical (cotton grass). However, alien invasive plants, such as Salix babylonic (weeping willow) Bidens pilosa (cobbler's pegs or Spanish needle), Melia azedarach (bead-tree or Cape lilac), Arundo donax (giant reed or Spanish cane), Pennisetum clandestinum (kikuyu grass) also occur (ARC, 2000; Dlamini, 2011; LRI, 2011). Animal species include Guinea fowl, insects, reptiles and amphibians, typical of the species types associated with Highveld watercourses (ARC, 2002). The Libradene wetland has been exposed to a long period of illegal, informal dumping of domestic waste and building rubble, although much of this has ceased in recent years due to better law enforcement by the Ekurhuleni Municipality. Such secondary impacts include storm water trenches to partially drain the wetland, as a few houses were built within the floodline (Pavlakis, 2001).

\section{South Africa's environmental legislation}

Wetlands enjoy protection under a number of pieces of legislation, and a summary thereof is provided in Table 1 . However, confusion can arise as to which act is applicable, when, and which authority must manage each case (Van Wyk, 2007). In the case of the Libradene wetland, CARA (Act 43 of 1983) is relevant as in terms of the Johannesburg Town Planning Scheme of 1979 it was originally zoned as agricultural land (Carron, 2009). The Environmental Conservation Act 73 of 1989 (ECA) - Section 21 and Section 23(2) - is relevant to the land use changes the petrol station wrought. A permit would have to be obtained to comply. The National Water Act (No 36 of 1998) (NWA) - Section 21 \& 22 which stipulates that any measures to impede or divert the flow of water in a watercourse, alter the bed, banks, course or characteristics of a watercourse requires a water use licence applies. However, as the site is a wetland, in terms of Section 22 (1a) the water use licence would have been denied as the erection of petrol stations on wetlands is specifically excluded from the list of permissible water-use regulations.

The most important act appling to the Libradene issue, is the National Environmental Management Act 107 of 1998 (NEMA). NEMA makes special reference to wetlands, stating that they require specific attention in management and planning procedures, especially where they are subject to significant human resource usage and development pressure. NEMA has two important measures to promote the role of the public in protecting the environment (Oliver et al., 2009). Firstly that of locus standi [see Section 31 and 32] that is members of the public can launch legal action in order to protect the environment, even if they themselves are not directly affected and secondly, the protection of whistle-blowers from civil or criminal liability, dismissal, disciplinary actions, prejudice or harassment on account of having disclosed information. The most significant aspect of NEMA (see Sections $23 \& 24$ ) is that of the requirement for developers to undertake an Environmental Impact Assessment (EIA). With regards to EIAs, NEMA draws on prior legislation, namely the Environment Conservation Act (ECA) (Act No. 73 of 1989). Thus, NEMA presents framework legislation, which until then had been lacking, and replaces most of the ECA (Sowman et al.,1995, Van Wyk, 1999). This is typical of many developing countries (Bekhechi \& Mercier, 2002). In particular, an EIA identifies all the social, economic and environmental impacts of activities, including disadvantages and benefits (Kidd \& Retief, 2009). Thus, EIAs are a pro-active and systematic process (Van Niekerk, 2004). Its purpose is to inform decision makers of the desirability of proposed activities and on the conditions which authorisation of the activity should be subject to (Saidi, 2010). EIAs are not without controversy, with a 
number of scholars noting their shortcomings such as poor methodological systems, being drawn up by inexperience people and being less than scientifically rigorous (Hugo et al., 1997; Biswas \& Geping, 1999; Hill, 2000; Saidi, 2000; Van Niekerk, 2004; Munster, 2005; Petts, 2007; Armstrong, 2009; Aucamp, 2009). This is despite NEMA Section 24 (a)-(i) providing and outlining minimum EIA requirements. (Mantzara, 1998; Murombo, 2008).

Table 1: Summary of National Legislation relevant in the Libradene case.

\begin{tabular}{|c|c|c|}
\hline ACT & SECTION & IMPORTANCE \\
\hline \multirow[t]{3}{*}{$\begin{array}{l}\text { The Constitution of South } \\
\text { Africa: Bill of Rights }\end{array}$} & $10 ; 11 ; 14$ & $\begin{array}{l}\text { Introduces legislation to prevent pollution and } \\
\text { ecological degradation in general }\end{array}$ \\
\hline & 24 & $\begin{array}{l}\text { Recognises that humans have the right to an } \\
\text { environment that is not harmful to their health and } \\
\text { well-being }\end{array}$ \\
\hline & $26 ; 27 ; 28$ & Promotes sustainable development \\
\hline $\begin{array}{l}\text { National Water Act } 36 \text { of } 1998 \\
\text { (NWA) }\end{array}$ & $19 ; 21 ; 22 ; 26$ & $\begin{array}{l}\text { Ensures the protection, conservation, use, management, } \\
\text { control and development of water resources, including } \\
\text { wetlands, in a sustainable and equitable manner }\end{array}$ \\
\hline $\begin{array}{l}\text { Environment and Conservation } \\
\text { Act } 73 \text { of } 1989 \text { (ECA) }\end{array}$ & $28 ; 31 \mathrm{~A} ; 41 \mathrm{~A}$ & $\begin{array}{l}\text { Prohibits activities that could harm the environment } \\
\text { and ensures that steps be taken against any person } \\
\text { causing such harm in order to remedy the cause }\end{array}$ \\
\hline $\begin{array}{l}\text { National Environmental } \\
\text { Management Act } 107 \text { of } 1998 \\
\text { (NEMA) }\end{array}$ & $\begin{array}{l}\text { 4A; 23B; } 28 \\
\text { Chapter } 1\end{array}$ & $\begin{array}{l}\text { Provides relevant principles to promote environmental } \\
\text { management and decision-making processes; } \\
\text { Ensures protection, evaluation, and the prediction of } \\
\text { potential impacts on the environment; } \\
\text { Ensures that polluters "pay", and prevents pollution } \\
\text { from occurring, continuing or recurring. }\end{array}$ \\
\hline $\begin{array}{l}\text { Conservation of Agricultural } \\
\text { Resources Act } 43 \text { of } 1983 \\
\text { (CARA) }\end{array}$ & $\begin{array}{l}\text { Regulations: } 4 \text {; } \\
\quad 7 ; 8,13\end{array}$ & $\begin{array}{l}\text { Ensures the protection of the soil, the regulation of the } \\
\text { flow pattern of run-off water, as well as the exploitation } \\
\text { of wetlands. }\end{array}$ \\
\hline
\end{tabular}

\section{Managing threats to wetlands}

There are differing international policy stances on wetland management. Some countries regard wetlands as critical conservation areas, while others perceive them as important agricultural development resources (Boyer \& Polasky, 2004). However, almost all natural wetlands are either modified and/or degraded, either for industrial development, urban expansion or for conversion to agricultural activities (Kotze et al., 1995; Moser et al, 2002). One of the most common urban practices is to fill them in with rubble or soil (Azous \& Horner, 2000). Many of these impacts are occurring in spite of environmental legislation and government policies designed to protect them (Boyer \& Polasky, 2004). Some argue that the legislation affecting wetlands is ineffectual as there seems to be an apparent reluctance on the part of administrators to apply it (Kotze et al., 1995). It is not clear whether the authorities, who make the decisions that impact upon the wetlands, are well-informed about the consequences of their decisions on these vulnerable areas. Alternatively, economic development has been prioritised above the conservation of the environment. Thus, it has been suggested, that wetland management practices be incorporated into integrated land- and water-use management. Furthermore, policies, strategies, and management plans for the 
sustainable exploitation and conservation of wetlands should be based on a solid knowledge and understanding of the ecological and socio-economic functions and processes associated with wetlands (Byomkesh et al, 2009). One of the major constraints to the sustainable management of wetlands is that wetland-users and decision-makers often lack knowledge of alternative management and policy regimes (Jogo \& Hassan, 2010). For example, there is little documented information on the impacts of alternative wetland management and policy regimes.

In South Africa, wetlands then, are the 'cinderellas' of the environmental management world. That is, wetlands face neglect, with academic studies into the state of wetlands, number of dedicated wetland officials and policies (as opposed to laws) dedicated to protecting wetlands from impacts and rehabilitating them, for example, lagging far behind that of rivers (Day, 2009). South Africa's most dedicated response to the threats wetlands face to date, has been the Working for Wetlands programme (WfW) - a wetland rehabilitation initiative. Although WfW does a lot of good work, its focus is on job creation and poverty alleviation rather than on wetland protection and rehabilitation, makes it primarily a public works programme (Working for Wetlands, 2012). Thus, South African wetlands are experiencing intense and sustained pressure and stresses from a range of direct and indirect socio-economic driving forces, especially development (Cilliers et al., 2003; Driver et al., 2005; Turner et al., 2007; McInnes, 2010).

There are a few well-known examples of small urban wetlands are under threat (Hartdegen, 2011). In Cape Town, the Princess Vlei wetland area is threatened by a proposed shopping mall and taxi rank (Adendorff, 2010; Masondo, 2011). In Gauteng, the Bishops Glen wetland - home to the threatened Giant Bull Frog - was severely degraded by a housing development (Mlambo, 2005). After a site visit to Bishops Glen, government officials issued a cease and desist directive to the developer, which was ignored. Although an interim court order was obtained, it was also ignored. The buildings were completed and the housing units put up for sale. Eventually bad publicity curtailed the sales of the units. The developer is currently facing charges of violation of various environmental regulations and contempt of court (GCA, 2005). Also in Gauteng, was the erection of the Pan-African Parliament on a wetland in 2008. Initially the construction complied with legislation as a positive Record Of Decision (ROD) was issued. Soon construction workers began to complain of excessive water on the site. Eventually engineers called in wetland specialists who classified the site as a hillslope wetland with a large seepage area. The wetland by that stage had been irreparably damaged by excavations for the main foundations (Fairall, 2011). The ROD was revoked (Adendorff, 2010). The Environmental Assessment Practitioner, Stefan Frylinck, and his firm, Mpofu Consulting, were charged with contravening the 2006 EIA regulations - as incorrect and misleading information - had been submitted to obtain the original ROD (Modise \& Singh, 2011). Frylinck and Mpofu Consulting CC were sentenced in the Pretoria Regional Court. Frylinck to two years imprisonment or a fine of R80 000, Mpofu Consulting $\mathrm{CC}$ to a fine of R80 000. Half the total was suspended for five years providing neither contravene Section 81 of the EIA Regulations again (Fairall, 2011). Modise \& Singh, 2011). This was the maximum penalty for such an offence under the regulations that were in place at the time. These same penalties have since been increased in accordance with the new 2010 EIA regulations to R1 million or one year of imprisonment (Fairall, 2011). Rehabilitation plans for the wetland are currently undergoing a public participation process. 


\section{Findings: The series of events}

In 1999, ownership of the land upon which the wetland is located was transferred from the Ekurhuleni Metropolitan Municipality to Dealmania (Pty) Ltd (ARC, 2002; Tip, 2006; Carron, 2009). Dealmania (Pty) Ltd later argued that, as the property owners, they automatically had the right to develop the land (Tip, 2006). However, property rights in South Africa do not give the owner exclusive rights to any natural resources found on the property and the ensuing court case between Petro Props (Pty) Ltd and Ms Nicole Barlow confirmed this (Cawood \& Minnitt, 1998). In 2000, Dealmania (Pty) Ltd tasked African Resource Consultants (ARC) as environmental consultants with obtaining the necessary authorisation for a change in land use. This step indicates that both Dealmania (Pty) Ltd and ARC recognised that they had to comply with environmental legislation. As a consequence, a basic scoping report commenced (with an application in this regard was submitted to GDACE) and did the Public Participation Process (PPP). GDACE conducted a site visit and subsequently gave ARC the go ahead to conduct the basic scoping report (L Serobatse, pers comm, July, 18, 2000). Although ARC claimed that the proposed development was advertised on site, in a local and in a regional newspaper, only two people (both local homeowners) were officially registered as Interested and Affected Parties (IAPs). According to ARC, both supported the development at that stage (ARC, 2002). The local councillor for the area, did not register as an IAP and there is no way of knowing if the councillor knew of the proposed development at this stage. However, in October, 2000, C Tydeman, one of the listed IAPs, writing on her own behalf as well as that of the other listed IAP, withdrew their support, maintaining that they had only been in favour of the development based on information provided by the developer which turned out to incorrect ( $\mathrm{C}$ Tydeman, pers comm, October, 24, 2000).

The geotechnical investigation proceeded in 2001, with engineers, Michael Pavlakis and Associates compiling a preliminary geo-hydrological report. This report found that the site was below the 1:50 year flood-line, within a shallow watercourse and where the groundwater table lay between 1.2 metres and 1.4 metres below the surface. Thus, a great deal of infilling, scarification and compaction would be required, along with the installation of reinforced steel stanchions or concrete piers, if development was to proceed (Pavlakis, 2001). Although the Pavlakis report succinctly describes a wetland, nowhere in the report is the site referred to as a wetland, nor are the severity of the impacts of the proposed development highlighted. It is left to the reader, who would need to know something about the location in particular, and wetlands in general, to infer it. The geotechnical study also omitted information on the soil properties, nor is any reference made to legislative hurdles that would have to be overcome to build on such a site. Omissions of this nature by a contracted professional are most concerning. This report was not made available to the general public, the IAPs or even, it seems, relevant government officials. There is no evidence that the authors of this report were ever held accountable for these omissions.

In 2002 the landowner/developer began to substantially deviate from standard basic scoping processes. They engaged lawyers, instead of the usual practice of appointing environmental consultants, to deal with government officials. No explanation for this unusual method was ever provided, nor was it questioned. Thus, Grutter \& Lombard Attorneys wrote to the then Department of Water Affairs and Forestry (DWAF) claiming that the Department of Environmental Affairs and Tourism (DEAT) was satisfied that the basic scoping report catered for the protection of the environment. An incomplete scoping report - prepared by ARC - was attached. No supporting evidence for DEATs position was ever provided, nor 
was any evidence provided that DEAT was ever involved. The attorneys further claimed that the landowner/developer was under pressure to finalise the scoping report in order to have the application for rezoning considered (Grutter, 2002). Once again, no evidence for this claim was ever presented, or asked for. K Chetty, a DWAF employee, responded to the attorneys, in the same year by: (1) instructing the parties to deal directly with the designated lead agent, namely GDACE; (2) noting that the basic scoping report was incomplete - as there was a lack of evidence that the local authority and the neighbouring East Rand Proprietary Mine (ERPM) had been informed about the inherent flooding problems the proposed development would present for their respective properties; (3) noting that no evidence was presented that the local authority had agreed to provide services; and (4) pointing out that, although the basic scoping report claimed that a hydrological census had been done and five boreholes identified, no details or maps of these boreholes had been included [thus the report lacked important information] (K Chetty, pers comm July, 12, 2002). To this end, Chetty, representing DWAF demanded that all parties needed to agree on a solution, proof of which had to be provided (Townsend, 2001).

The year 2003 was a significant one for the Libradene wetland. According to the developer, on the $6^{\text {th }}$ of January 2003, the HOD of the GDACE, Dr Hanekom, issued a positive ROD to Dealmania (Pty) Ltd and ARC, allowing the proposed development to proceed. According to GDACE, however, on the $6^{\text {th }}$ of January, 2003, the HOD of the GDACE, Dr Hanekom, issued a negative ROD, declining the proposed development for the construction of a filling station with a convenience store and an ATM facility, low residential office units and high density residential units (Hanekom, 2003). The negative ROD lists four reasons for declining the authorisation: (i) the development did not comply adequately with the requirements for an application for authorisation in terms of Section 22 of ECA, (ii) the site is within a wetland area and below the 1:50 year flood-line; (iii) as there were three other petrol stations located within a three-kilometre radius of the proposed site - with the closest being 1,5 km away - the development did not comply with the Development Facilitation Act (No. 67 of 1995) and Department's Guidelines for the Construction and Upgrading of Filling Stations and Associated Tank Installations of September, 20014 ; and (iv) the necessary requirements for achieving Integrated Environmental Management, as listed by NEMA would be violated if the development went ahead. As such, the proposed development could not be classified as one that would be environmentally, socially, and economically sustainable. In particular, with a residential area within 100 metres of the site the development would be socially insensitive.

It is highly likely that the original ROD was indeed negative, for the following reasons: (a) the negative ROD as presented is based on verifiable facts, such as the location of the various other petrol stations (see Figure 4); (b) on the $15^{\text {th }}$ of January, 2003, ARC wrote to the landowner/developer in which the "negative outcomes of the Libradene filling station environmental impact assessment procedure" is referred to (ARC, 2003). It is clear from the letter that an acrimonious meeting had taken place between ARC and the landowner/developer, who subsequently discharged ARC of its duties and undertook to personally "follow up on the scoping report" so as to appeal the decision of GDACE (C Pelissier, December, 18, 2003). The letter subsequently entered the public domain as part of

$4 \quad$ These guidelines were subsequently affirmed by the Fuel Retailers Association of Southern Africa v Director-General: Environmental Management, Department of Agriculture, Conservation and Environment, Mpumalanga Province, and others 2007 (6) SA 4 (CC). 
the court record and the authenticity of its contents was never questioned. Thus, it can be surmised that the ROD was indeed negative.

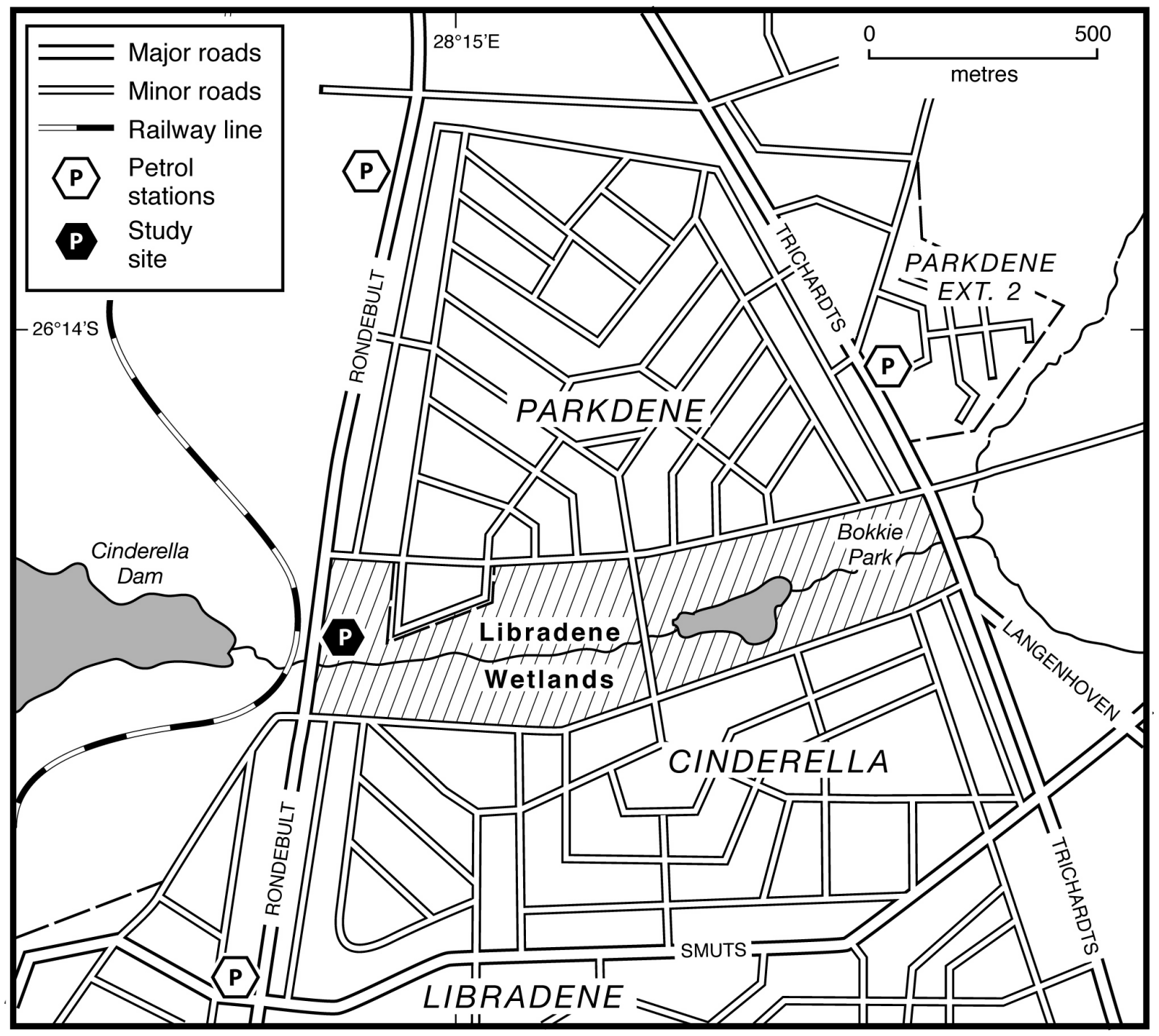

Figure 4: Relation of the three other petrol stations to the proposed development in

\section{Libradene}

In early December 2004, alerted by concerned members of the public, GDACE officials arrived at the site to find the site under construction and foreman dumping overburden onto another part of the same wetland, well beyond the footprint of the site. This was further damaging the wetland and encouraging secondary dumping by the public. The foreman had also diverted the storm water drain on the site as it had been affecting the site works. The official GDACE report suggested holding a meeting with the local authority to attempt to stop the development and requesting the developer suspend operations until an approved Environmental Management Plan (EMP) - dealing with water and site saturation issues for the site - had been submitted and approved (P Furniss, pers comm December, 10, 2004). GDACE also notified various governmental agencies, namely DWAF, the National Biodiversity Institute, and the Department of Agriculture, of the situation, as a coordinated efforts to mitigate the severe impacts would be required (Bahadur, 2004).

At this juncture, the developer produced a photocopy of a positive ROD dated 6 January 2033, which, at the time, could not be disputed as it was the only documentation available ( $T$ Ratsheko, pers comm October, 24, 2005). This was because a fire at the GDACE premises 
had destroyed all copies of the ROD, along with other key documents, such as the basic scoping report (Bahadur, 2004)5. Furthermore, contact with the environmental consultant (ARC) proved fruitless, as the firm was no longer operating and the consultant had emigrated. Despite these problems, procedurally it could be argued that GDACE may have made a critical error at this juncture, that is, an uncertified photocopy, of what was a very controversial ROD, was taken at face value. The developer was not asked to produce the original or any of the supporting documents (such as the full EIA that would have had to have been produced for a positive ROD to be issued, see Sandham et al 2013) that would have had to accompany the granting of a positive ROD. No reason for this was ever provided.

However, even if the ROD had indeed being positive, the developer was still acting illegally. That is, the development had commenced without the necessary EMP in place as required in terms of Section 22 of ECA and excavation operations had taken place well beyond the scope of the ROD, that is, in all three zones of the wetland (Cornelius, 2005). The Gauteng office of DWAF conducted a site in January 2005 and issued a report to the developer that DWAF had no objections to the development providing that 10 specific conditions were met. These included: a storm water management plan, the monitoring of the shallow water table, taking South African Board of Standards 089, 1535, 0131, 0108 and 0400 proviso's into account, and adherence to all relevant sections of NWA. DWAF indicated that as construction had commenced, this action would be construed as acceptance of these conditions. It was never made clear why DWAF issued such a report or if they had consulted GDACE on the matter. How DWAF was supporting co-operative governance and GDACE as the lead agent in the matter was also not made clear.

Despite such obvious violations, and written notification to that effect by various government agencies, construction continued. In response to this, in March, 2005, Ms Nicole Barlow, a local resident, founded the Libradene Wetland Association (LWA) in order to bring pressure to bear on the relevant authorities to intervene further (Tip, 2006). A media campaign was embarked upon whereby letters were sent to the local press, Sasol Oil (Pty) Ltd and the Minister of Environmental Affairs. Ms Barlow also met with DWAF and GDACE officials between the months of May and October 2005 (Tip, 2006). During this period, a further cooperative governance issue raised its head, when the local authority issued an approved rezoning application. Although the local authority was well within its rights to do so, it is unclear why this happened when it was well known that construction was not fully authorised.

In November 2005 matters took a positive turn when Sasol Oil (Pty) Ltd, who would have supplied Petro Props (Pty) Ltd with fuel products, agreed to GDACE's instruction to suspend construction for a period of two weeks. Whilst Sasol Oil (Pty) Ltd gave no official reason for this, it is speculated that the discovery of the original negative $\mathrm{ROD}^{6}$ (which demonstrated that the developer had not produced the genuine, original ROD), may have caused serious legal concerns for Sasol Oil (Pty) Ltd. Shortly thereafter, GDACE issued a notice of intention to issue a directive to Sasol Oil (Pty) Ltd and Petro Props (Pty) Ltd based new information pertaining to the ROD. At the same time, a Forensic Document Examiner also declared the signature on positive ROD to be of 'questionable authenticity'. GDACE

5 Thousands of documents were lost in this serious fire.

6 While on holiday in South Africa, the former director of ARC heard about the Libradene issue and then gave a copy of the negative ROD to the relevant authorities. 
informed both the developer and Sasol Oil (Pty) Ltd that unless an original positive ROD (and not an uncertified photocopy) was produced, the opinion of the Forensic Document Examiner would stand. On this basis, GDACE gave Sasol Oil (Pty) Ltd 48 hours to make a written representation as to why all construction activities should not be permanently suspended (Cornelius, 2005). With no reasons forthcoming, in December 2005, GDACE issued the directive in terms of Section 31A of ECA. The directive noted Petro-Props (Pty) Ltd ongoing refusal to cease construction, thus giving GDACE no option but to exercise its authority to direct the suspension of all activities related to the construction of the service station with immediate effect (Cornelius, 2005). GDACE also issued a press statement entitled 'Government halts construction of petrol station on wetland' where by the public was notified that the developer had been acting in opposition to policy and legislative obligations. GDACE acknowledged that local residents, environmental activists and the business community had complained extensively about the issue (GDACE, 2005).

In 2006, Petro-Props (Pty) Ltd sued Ms Barlow and the LWA for interfering with the development of the fuel station, claiming that their media campaign damaged the viability of the project by forcing Sasol Oil (Pty) Ltd to withdrawn from its contractual arrangements, with severe financial implications for Petro-Props (Pty) Ltd (Tip, 2006). It was clear that the relentless media campaign by Ms Barlow had served to pressure various stakeholders to take action. She had effectively become the 'public face' of the 'save the Libradene wetland' campaign, a role few were prepared to fill. The effect of pressure Ms Barlow brought to bear on both the authorities via the media cannot be underestimated. For example, an internal Sasol Oil (Pty) Ltd email, now part of the court judgement, reads as follows:

\begin{abstract}
The whole Libradene issue is doing serious damage to our reputation. I think we should seriously consider a formal announcement that we are withdrawing from the site and that we do not support Petroprops' R6 million lawsuit against Mrs Barlow. Mrs Barlow has featured as a 'national champion' on Radio 702 for two days now and listeners are calling for a boycott of Sasol CCs. She also featured in the Mail and Guardian. The saga has been on-going for well over a year now and not a single newspaper, radio or TV mention has so far favoured Sasol's stance. We are seen as the big bully. The fact that Petroprops is suing Mrs Barlow for a reported R6 million because she is trying to protect a wetland (for whatever reasons) is putting the spotlight on Sasol. The public are under the impression that this is done with the blessing of Sasol and that Sasol is supporting attempts to silence responsible individuals in pursuit of profits. I believe that the reputation fallout may in the end prove far more damaging to Sasol than the business case and that we should withdraw (Tip, 2006).
\end{abstract}

Tip ruled that Ms Barlow and the LWA had the right to complain in the media about the perceived poor conduct of government officials and so dismissed the case with costs (Tip, 2006). This High Court judgement [Petro Props (Pty) Ltd v Barlow and Another 2006 (5) SA $160(\mathrm{~W})]$ is considered a landmark one as it enshrines the rights of individuals to exercise their constitutional rights to a 'clean and healthy environment' and, thus, ensures that constitutional property rights do not trump this environmental right. The judgement also affirmed the right to object to an environmentally unacceptable development using a public awareness campaign (Barnard et al, 2011). While the outcome of the case vindicated Ms Barlow and the LWA, such litigation (with its associated high costs) launched by Petro Props (Pty) Ltd could be viewed as a classic Strategic Lawsuit Against Public Participation (SLAPP) suit - designed to get both parties to 'back down', remove public pressure and 
curtail negative publicity. Ms Barlow and the LWA were only able to defend themselves because a number of legal experts offered assistance pro bono. Furthermore, Ms Barlow had no attachable assets at the time, so should she have lost the case, she would not have faced financial ruin, a situation few environmental activists could have weathered.

In November, 2007 GDACE took Petro-Props (Pty) Ltd; Sasol Oil (Pty) Ltd and Dealmania (Pty) Ltd to court. Sasol Oil (Pty) Ltd did not oppose the application, but GDACE withdrew the case as both Petro-Props (Pty) Ltd and Dealmania (Pty) Ltd agreed to submit an Environmental Management Plan (EMP), which would include a new PPP, within 30 days. In the light of both Petro-Props (Pty) Ltd and Dealmania (Pty) Ltd's past behaviour, such light treatment by authorities is questionable. Instead of bringing the developer to book, this court order seemed to indicate that GDACE was prepared to allow the developer to proceed providing certain compliance issues were dealt with. Despite the court order, there is no evidence that this EMP or new a PPP was ever undertaken. GDACE never proceeded with full prosecution of Petro-Props (Pty) Ltd and Dealmania (Pty) Ltd for failure to comply with Environmental Impact Assessment (EIA) regulations; failure to comply with Chapter 5 of NEMA (107 of 1998); failure to comply with Section 22 of the ECA (73 of 1989) and failure to comply with CARA (43 of 1983). As a result, in November, 2008, Ms Barlow and her environmental organisation, Environment and Conservation Association, sought an interdict against GDACE, Petro-Props (Pty) Ltd and Dealmania (Pty) Ltd to force the demolition of the structures and rehabilitation of the wetland. To date, the case has still not been argued in court, due to multiple extensions granted between 2009 and 2011. No additional action from GDACE has been forthcoming. The partly built station still stands, it is still owned by Petro Props (Pty) (Ltd) who has repaid the bank mortgage loan raised against the development. Two security guards secure and manage the premises around the clock. At the time of writing the wetland remains a dump site, home to alien invasive plants and the remains of a half built petrol station.

In December 2011, DWV Environmental Consulting submitted a Basic Assessment Report (BAR) to the Gauteng Department of Agriculture and Rural Development (GDARD) on behalf of WfW. The proposed rehabilitation plan had three main objectives: (1) to improve the hydrological integrity of the wetland system by deactivating trenches and re-wetting the entire wetland; (2) to improve the geomorphological and vegetational integrity of the wetland by removing the dumped material and litter and (3) to restore the original flooding pattern (DWV, 2011 \& 2012; LRI, 2011). Although this represents the most significant progress that has been made towards the rehabilitating of the wetland to date, WfW subsequently suspended it in March 2012, as a wider rehabilitation programme for multiple East Rand wetlands was proposed.

\section{Analysis and recommendations}

An analysis of the events seems to indicate that the environmental legislation in place did serve its purpose as the initial application was declined by GDACE. Thus, the main role player responsible for the destruction of the wetland was the developer, who deviated from procedures, made unsubstantiated claims to authorities, ignored written instructions to cease construction and defied a court order. However, some responsibility has to be borne by government officials, as law enforcement was weak and slow. In addition, it could be argued that GDACE officials should not have agreed to the basic scoping process in the first place, because a wetland was involved. Furthermore, some responsibility needs to be assumed by the professional consultants involved, for undertaking the task of applying for authorisation for a 
petrol station on what was obviously a wetland ${ }^{7}$. Thus, it could possibility be argued that proceeding with the basic scoping process may have falsely led the land owner/developer to believe that his request to erect a petrol station would be dealt with favourably. It leads to a questioning if officials can easily reject basic scoping report requests? For example, if the wetland had been recorded in the national wetland database would this have helped officials in rejecting the basic scoping request? Or do environmental consultants and government officials need additional training on wetland identification and wetland protection so as to be more empowered to decline such requests?

Another serious issue is that law enforcement took a long time, during which construction continued, resulting in significant damage to the wetland. While delays were partly due to the non-cooperation of the developer, an environmental consultant who had emigrated and missing documentation, the effect of justice delayed was justice denied. Both DWAF and GDACE could have been more forceful in stopping construction, because even if the ROD had been genuinely positive, the lack of an approved EMP gave them sufficient grounds to institute legal proceedings. This then begs the question as to how empowered are government officials when it comes to dealing with non-compliance? In addition, the actions of DWAF and the local authority at crucial junctures could be construed as unintentionally undermining the authority and decision-making power of the responsible provincial authority, namely GDACE. That is, the basic scoping report should have been rejected out of hand due to its incompleteness and GDACE should have been copied on all correspondence. Whilst the national legislation is quite clear in its intentions concerning water resource conservation and protection, the relationships - and the lines of responsibility - between the institutions at the national, provincial and local levels are often entangled. Processes and procedures are complex and confusing, the consequences of which is inefficiency, uncoordinated planning, division of control, fragmentation and intergovernmental conflicts such as the one described here. It was clear that the developer was able to exploit this situation. It is clear that document control is vital, with the fire at the GDACE premises highlighting the inadequate provision of secure back-up copies. Additionally, if all relevant stakeholders, as an established practice, had been sent copies of the original ROD, it is less likely that the developer could have seized the opportunity to create a forgery. Importantly, South African law requires all documentation be kept for five years, so avenues need to be explored to establish how to ensure environmental consultant firms can be bound to this even in the event of closure or emigration.

The case highlights the importance of conducting effective public participation, that is, public participation should be broad based, with all community members who stand to be affected, consulted. This leads one to question how adequately does South Africa's legislation deal with public participation? NEMA Section 24(d) specifically demands public participation with the purpose of providing all interested and affected parties with an opportunity to participate in procedures and access information (Nanda \& Pring, 2003; George \& Kirkpatrick, 2007). However, clarity on what the obligations regarding PPP for an environmental consultant are, is needed; along with better guidelines pertaining to PPP best practice. This includes clarifying if developers can get directly involved in the PPP and if

$7 \quad$ The poor performance of the various professionals involved means that the findings of Earthlife Africa (Cape Town) v Director-General: Department of Environmental Affairs and Tourism and another 2005 (3) SA 156 (C) may have relevance here. Perhaps EIA oversight consultants/specialists should be appointed by an independent authority to ensure that basic scoping reports are accurate? 
developers can provide information, that is not shared with the general public, directly to an IAP. Lastly, considering how few responses were received, one wonders if the general South African public is fully aware of what the PPP is; what an IAPs is; and what their rights are? If so, then who should be tasked with informing the public as to what their rights are, the environmental consultants, government agencies or both? Furthermore, what can be considered suitable awareness raising? These particular issues have not been addressed in the publication of new NEMA Regulations in 2006 or the August 2010 revised EIA regulations (see Government Gazette 33306). The revised regulations were aimed at improving the efficiency and effectiveness of EIAs, making authorities accountable in terms of deadlines with respect to decisions and changing aspects of the public consultation - such as excluding the period December 15 - January 2 in the counting of days for decisions and lodging of appeals and a requirement that decisions must be published in the same newspaper used during the PPP (Saidi, 2010).

As was the case for Libradene, it is clear that not all developers, environment consultants and experts in the field acknowledged their obligations in terms of adhering to environmental legislation. It is of utmost importance, therefore, that a wetland protection strategy programme is implemented in order to (1) improve both regulatory and non-regulatory wetland protection; (2) educate and promote awareness amongst the public on the ways in which wetlands function in the context of an ecosystems approach, and to emphasise their value and importance; (3) impose penalties on those who damage and exploit wetlands; (4) place the responsibility of maintaining a healthy wetland on all South Africans; (5) improve the quality and amount of information on wetlands and their intrinsic value to the environment and society, and (6) communicate it more effectively to all levels of authority. This case also demonstrated the vital role eco-crusaders - such as Ms Nicole Barlow - play in protecting the environment (Murombo, 2008). If it were not for Ms Barlow, empowered by the provisions of the South African Constitution, assisted by the media and displaying a selfless interest in the Libradene wetland, it is not clear if the development would have been stopped. In particular, her relentless pressure galvanised the internal GDACE investigation (which revealed the forgery) and secondly the constant media coverage alerted the director of ARC to the situation whilst he was on holiday in South Africa, resulting in his submission of a copy of the negative ROD to GDACE. Lastly, the construction of a petrol station on the Libradene wetland highlights some key challenges regarding sustainable development which involves balancing economic development and environmental protection. On the one hand there is considerable pressure by landowners and developers to invest in their assets and increase their nett material wealth. On the other hand, urban areas need to be managed in an environmentally and socially sustainable manner. This often results in conflict, as this case demonstrated, between those who see the need to increase the extent and value of the built environment and those who feel urban open spaces and habitats such as urban wetlands must be preserved. Thus, it is important that all basic scoping reports and, subsequent EIAs, include a cost/benefit analysis whereby short and long term social and environmental gains and losses are weighed up.

\section{Conclusion}

The Libradene wetland case, although not a significant wetland, highlights a number of challenges facing good environmental management. Firstly, co-operative governance is fraught with difficulties, as delineated lines of responsibility and authority are not always clear. Thus, greater attention needs to be paid to improving relationships between 
government departments. For example, designated lead agents should be copied on all correspondence by all other state bodies in order to 'give life' to cooperative governance. Secondly, consolidation of legislation at the national level (or, alternatively, the coordination of provincial legislation to align the respective laws of the provinces with environmental legislation at the national level), with the aim of protecting wetlands, is required. Thirdly, enforcement and administration of the law naively assumes stakeholders will voluntarily comply, which is not always the case. Thus, authorities should promote compliance by developers and environmental practitioners by (a) demanding adherence to stringent environmental management standards (such as rejecting incomplete scoping reports out of hand); (b) streamlining enforcement procedures under one lead agent; (c) strengthening the public participation process to ensure all relevant stakeholders are aware of proposed developments and their concerns are met; and (d) making active use of the national wetlands database to identify wetlands upfront.

\section{References}

Adendorff H. (2010) South Africa's wetland crisis. Available from: http://myfundi.co.za. Accessed 23 January 2012.

African Resource Consulting (ARC) (2000) Background Document for Scoping, Libradene Service Station, prepared for Dealmania (Pty) Ltd.

African Resource Consulting (ARC) (2002) Scoping report for Libradene Filling Station prepared for Dealmania (Pty) Ltd.

African Resource Consulting (ARC) (2003) Clarification of issues raised at the meeting held to discuss the negative outcome of the Libradene Filling Station Environmental Impact Assessment procedure, Letter issued to Dealmania (Pty) Ltd.

Armstrong A. (2009) WET-Legal: Wetland rehabilitation and the law in South Africa. Water Research Commission Report No. TT 338/09. Water Research Commission, Pretoria.

Aucamp P.J. (2009) Environmental impact assessment-a practical guide for the discerning practioner. Van Schaiks Publishers, Pretoria, South Africa.

Azous A and Horner R.R. (2000) Wetlands and Urbanization: Implications for the Future CRC Press: USA.

Bahadur U. (2004) Libradene Filling Station, email to notify others of the development.

Barnard D. Barnard C. Massyn N. and Botha T. (2011) Road Map to Environmental Legislation, South Africa: Impact Books.

Bekhechi M.A. and Mercier J.R. (2002) The Legal and Regulatory Framework for Environmental Impact Assessments, Washington: The World Bank.

Biswas A.K. and Geping Q. (1999) Environmental Impact Assessment in Developing Countries, Oxford University Press, London.

Boyer T. and Polasky S. (2004) Valuing Urban Wetlands: a review of non-market valuation studies. The Journal of Wetland Scientists 24:744-755.

Braak A.M. Walters D. and Kotze D.C. (2000) Practical Wetland Management South Africa: Rennies Wetland Project. 
Byomkesh T. Nakagoshi N. and Shahedur R.M. (2009) State and management of wetlands in Bangladesh. Journal of Landscape Ecological Engineering 5: 81-90.

Carron G.M.M. (2009) The relationship between planning and environmental management in Gauteng. MSc thesis: University of Witwatersrand. South Africa.

Cawood F.T. and Minnitt R.C.A. (1998) A historical perspective on the economics of the ownership of mineral rights ownership. Journal of the South African Institute of Mining and Metallurgy 98: 369-376.

Cilliers S.S. Muller N. and Drewers E. (2003) Overview on Urban nature conservation: situation in the western-grassland biome of South Africa. Urban Forestry and Urban Greening 3: 49-62.

Cornelius S. T. (2005) Notice of Intention to issue a directive in terms of the Section 31A of the Environment Conservation Act of 1989 (Act 73 of 1989): Proposed Filling Station on Portion 125 of the Farm Leeuwpoort $113 \mathrm{JR}$, Boksburg, Letter to Dealmania (Pty) Ltd.

Day J.A. (2009) Rivers and Wetlands. In Strydom, HA and King ND (eds) Fuggle and Rabie's Environmental Management in South Africa, Cape Town: JUTA.

Dini J. Cowan G. and Goodman P. (1998) South African National Wetland Inventory: Proposed Wetland Classification System for South Africa, Pretoria.: Dept of Environmental Affairs and Tourism.

Dlamini B. (2011) A health and ecosystems services assessment of wetlands for the planning of rehabilitation. Wetlands Consultancy Services. Wetland Assessment: C22B-04-A.

Driver A. Maze K. Rouge M. Lombard A.T. Nel J. Turpie J.K. Cowling R.M. Goodman R.J., Harris J. Jonas Z. Reyers B. Sink K. and Strauss T. (2005) National Spatial Biodiversity Assessment. Pretoria: South African National Biodiversity Institute.

DWV (2011) Background information document, Environmental basic assessment process for the proposed rehabilitation of the Libradene Wetland, Boksburg, South Africa. Ref Number: GDARD Ref No: GAUT 002 / 11 - 12 / E 0144.

DWV (2012) Environmental basic assessment process for the proposed rehabilitation of the Libradene Wetland, Boksburg, South Africa. GAUT Ref Number: GAUT 002 / 11 12 / E 0144.

Fairall P. (2011) Gauteng-Pan African Parliament, Midrand. Available from: http://www.wetlands.za.net/discussion/viewtopic.php?t=69. Accessed 5 February 2012.

GCA (2005) Gauteng Conservancy Association (GCA) Newsletter 6. Available from: http://www.conservancies.org/Downloads/Ear\%20to\%20the\%20Ground6.pdf. Accessed: 28 May 2011.

GDACE (2005) Government halts construction of petrol station on wetland, media release from the office of the MEC to News Editors, $8^{\text {th }}$ December.

George C. and Kirkpartrick C. (2007) Impact assessment and sustainable development: an introduction. In C. George and C. Kirkpartrick, (eds). Impact assessment and sustainable development: European practice and experience. United Kingdom: Edward Elgars Publishing Ltd.

Grutter M. (2002) Libradene Filling Station: Cinderella Dam, Letter to DWAF regarding submission of scoping report.

Hanekom P. (2003) Authorisation of the proposed development of a Libradene Filling Station, Libradene, Boksburg, Record of Decision (ROD) issued by GDACE. 
Hartdegen P. (2011) Wetlands trashed by developers. Available from: http://www.property24.com/articles/wetlands-trashed-by-developers/13089. Accessed 24 May 2012.

Heydorn A.F. (1996) Human population growth, land-use planning and wise wetland management - A challenge for the future. South Africa: World Wildlife Fund.

Hill R.C. (2000) Integrated environmental management systems in implementation of projects. South African Journal of Science 96: 50 - 54.

Hugo M. L. Viljoen A. T. and Meeuwis, J.M. (1997) The Ecology of Natural Resource Management: The Quest for Sustainable Living, A Text for SA Students, Pretoria: kagiso Publishers.

Jogo W. and Hassan R. (2010) Balancing the use of wetlands for economic well-being and ecological security: the case study of Limpopo wetland in Southern Africa. Ecological Economics 69: 1569-1579.

Kidd M. and Retief F. (2009) Environmental assessment. In Strydom, HA and King ND (eds) Fuggle and Rabie's Environmental Management in South Africa. Cape Town, JUTA.

Kotze D.C Breen C.M. and Quinn N. (1995) Wetland losses in South Africa. In: Cowan G.I. (ed) Wetlands of South Africa. Pretoria: Department of Environmental Affairs and Tourism.

LRI (2011) Rehabilitation Plan: Libradene Wetland. Report No: L03658/280611/2.

Mantzara B. (1998) Public participation: guidelines for the organisation of round table

discussion. Greece: Mediterranean information office for environment culture and sustainable development.

Masondo S. (2011) Wetlands Crisis: Developers, mines, local government blamed. Available from: $\quad$ http://www.wetlands.za.net/gauteng/press/satimes_08feb2011-01.pdf. Accessed: 24 May 2012.

McInnes R. (2010) Urban Dervelopment, Biodiversity and Wetland Management. Expert Workshop Report. Oxford. UK.

Mlambo I. (2005) New provincial task force prepares to sting developer ruining a wetland. Available from: http://www.sundaytimes.co.za. Accessed 5 February 2012.

Modise A. and Singh R. (2011) Department of Environmental Affairs welcomes the sentencing of Pan African Parliament (PAP) environmental consultant and firm. Available from: http://www.info.gov.za/speech/DynamicAction?pageid=461andsid=17943andtid=324 56. Accessed 5 February 2012.

Moser M. Prentice C. and Scott S. (2002) A global overview of wetland loss and degradation. Wetlands International. www.ramsar.org. Accessed 28 January 2012.

Mucina L. and Rutherford M. C. (2006) The vegetation of South Africa, Lesotho and Swaziland. Strelitzia 19. South African National Biodiversity Institute, Pretoria.

Munster F. (2005) Guidelines for Determining the scope of specialist in involvement of EIA processes. Ed.1. CSIR Report ENV-S-C 2005 053A. Cape Town.

Murombo T. (2008) Beyond public participation: the disjuncture between South Africa's environmental impact assessment (EIA) law and sustainable development. PER: Potchefstroomse Elektroniese Regsblad 11: 1727-3781.

Nanda V. P. and Pring G. (2003) International environmental law and policy for the $21^{\text {st }}$ century. New York: Transnational Publishers, Inc.

Oliver N.J.J. Myakayaka A.G. and Richards R.L. (2009) Indigenous plants. In Strydom, H.A. and King N.D (eds) Fuggle and Rabie's Environmental Management in South Africa, Cape Town: JUTA. 
Pavlakis M. (2001) Preliminary Geotechnical Investigation for the Libradene Development including A Service Station in Boksburg. Report No. 2341. Michael Pavlakis and Associates consulting Geotechnical Engineers.

Petts J. (ed) (2007) Handbook of Environmental Impact Assessment, Vol 1 - Environmental Impact Assessment: Process, Methods and Potential Oxford: Blackwell Science Ltd.

Saidi T.A. (2000) Integrating Environmental Issues in Project Planning and Implementation. Thohoyandou: School of Environmental Science Monograph, University of Venda.

Saidi T.A. (2010) Environmental Impact Assessment as a policy tool for integrating environmental concerns in development. AISA POLICY BRIEF 19: 1-7.

Sandham L.A., van Heerden A.J., Jones C.E., Retief F.P. and Morrison-Saunders A.N. (2013) Does enhanced regulation improve EIA report quality? Lessons from South Africa. Environmental Impact Assessment Review 38: 155-162.

Sowman M. Fuggle R. and Preston G. (1995) A review of the evolution of environmental evaluation procedures in South Africa. Environmental Impact Assessment Review 15: 45-47.

Tiner R.W. (1999) Wetland indicators: A guide to wetland identification, delineation, classification and mapping, Lewis: US.

Tip K. (2006). Case 29663/05: Petra Props (Pty). Ltd v. Barlow and Libradene Wetlands Association; High Court of South Africa - Witwatersrand Division.

Townsend P. (2001) Extent of Flooding caused by ERPM Embankment across Eastern Watercourse into Cinderella Dam, at a crossing with Rondebult Road Boksburg. Townsend and Associates.

Turner R.K. Eorgiou S.T. Brouwer R. Batemana I.J. and Langford I. (2007) Towards an integrated environmental assessment for wetland and catchment management. The Geography Journal 169: 99-116.

Van Niekerk L. (2004) An EIA of Rietvlei farm's development as a conservation area within JMOSS management guidelines. Unpublished MSc dissertation, University of Johannesburg.

Van Wyk J. (1999) Planning Law: principles and procedures of land-use management; Kenwyn: Juta.

Van Wyk J. (2007) The impact of development on the environment as part and parcel of integrated development planning? Law, Democracy and Development 11: 57-79.

Working for Wetlands (2012) Available from: http://wetlands.sanbi.org/. Accessed 18 January 2012. 